\title{
Influence of Selected Iron Correctors to Solidification of Secondary AISi10MgMn Alloy
}

\section{Maria Zihalova ${ }^{1}$, Dana Bolibruchova ${ }^{1}$, Jaromir Cais ${ }^{2}$}

${ }^{1}$ Department of Technological Engineering, Faculty of Mechanical Engineering, University of Zilina, Univerzitna 8215/1, 01026 Zilina. Slovak Republic. E-mail: maria.zihalova@fstroj.uniza.sk, danka.bolibruchova@fstroj.uniza.sk

${ }^{2}$ Faculty of Production Technology and Management, J. E. Purkyne University in Usti nad Labem. Pasteurova 3334/7, 40001 Usti nad Labem. Czech Republic. E-mail: cais@ fvtm.ujep.cz

Secondary (recycled) aluminium alloys are still not widely used in the foundry industry, because of the higher amounts of impurities that require more strictly control of the manufacturing process. The most problematic impurity of aluminium cast alloys is iron, which is in alloy mostly present in form of hard and brittle intermetallic phases. Such phases are thought to be detrimental to alloy mechanical and foundry properties and have to be removed or modified to eliminate negative effects. Several techniques might be used to this purpose, from which the most beneficial seems to be addition of some elements, so-called "iron correctors". Influence of the iron correctors can be also analysed by thermal analysis that serve as a tool to prediction of solidification behaviour of the alloy. Influence of $\mathrm{V}, \mathrm{Cr}$ and $\mathrm{Ni}$ (alone and in selected combinations) to solidification behaviour of AISi10MgMn alloy with increased iron level is presented in this article. Selected iron correctors influenced temperatures of thermal arrests representing formation of primary aluminium, iron intermetallics and also eutectic silicon.

Keywords: AlSi10MgMn alloy, Intermetallic phase, Iron correctors, Thermal analysis

\section{Acknowledgement}

This research was created within the framework of the grant project VEGA $N^{\circ} 1 / 0363 / 13$. The authors acknowledge the grant agency for support.

\section{References}

[1] DINNIS, C.M., TAYLOR, J.A., DAHLE, A.K. (2005). As-cast morphology of iron-intermetallics in Al-Si foundry alloys. In: Scripta Materialia, Vol. 53, pp. 955 - 958.

[2] PETRIK, J., HORVATH, J. (2011). The iron correctors in Al-Si alloys. In: Annals of faculty engineering Hunedoara, Vol. 9, No. 3, pp. $401-405$.

[3] HURTAlOVA, L., TILlOVA, E. (2013). Elimination of the negative effect of Fe-rich intermetallic phases in secondary (recycled) aluminium cast alloy. In Manufacturing Technology, Vol. 13, No. 1, pp. 44-50

[4] KRIVOŠ, E., PASTIRČÁK, R., MADAJ, R. (2014). Effect of technological parameters on the quality and dimensional accuracy of castings manufactured by patternless process technology. In: Archives of metallurgy and materials, Vol. 59, No. 3, pp. 1069-1072.

[5] TAYLOR, J.A. (2004). The effect of iron in Al-Si casting alloys. In: $35^{\text {th }}$ Australian Foundry Institute National Conference, pp. 148 - 157, Adelaide, South Australia.

[6] CAO, X., CAMPBELL, J. (2006). Morphology of Al5FeSi phase in Al-Si cast alloys. In: Materials Transactions, Vol. 47, No. 5, pp. $1303-1312$.

[7] TAYLOR, J.A. (2012). Iron-containing intermetallic phases in Al-Si based casting alloys. In: Procedia Materials Science, Vol. 1, pp. 19 - 33.

[8] HEUSLER, L., SCHNEIDER, W. (2002). Influence of alloying elements on the thermal analysis results of Al-Si cast alloys. In: Journal of Light Metals, Vol. 2, pp. 17-26.

[9] CANALES, A.A. et al. (2010). Thermal analysis during solidification of Al-Si alloys. In: Thermochimica Acta, Vol. 510, pp. 82-87.

[10] KUMARI, S.S.S., PILLAI, R.M., RAJAN, T.P.D., PAI, B.C. (2007). Effects of individual and combined additions of $\mathrm{Be}, \mathrm{Mn}, \mathrm{Ca}$ and $\mathrm{Sr}$ on the solidification behaviour, structure and mechanical properties of $\mathrm{Al}-7 \mathrm{Si}-0.3 \mathrm{Mg}-0.8 \mathrm{Fe}$ alloy. In: Material Science and Engineering A, Vol. 460-461, pp. 561 - 573.

[11]PASTIRCAK, R. (2014). Effect of Low Pressure Application during Solidification on Microstructure of Al-Si Alloys. In: Manufacturing Technology, Vol. 14, No. 3, pp. 397-400.

[12]BRUNA, M., KUCHARCIK, L., SLADEK, A. (2013). Complex evaluation of porosity in A356 aluminium alloy using advanced porosity module. In: Manufacturing Technology, Vol. 13, No. 1 pp. 26-30.

Paper number: M201662

Copyright $@$ 2016. Published by Manufacturing Technology. All rights reserved. 